\title{
Hepatitis A Virus Genome Organization and Replication Strategy
}

\author{
Kevin L. McKnight and Stanley M. Lemon \\ Departments of Medicine and Microbiology \& Immunology, Lineberger Comprehensive Cancer Center, \\ The University of North Carolina, Chapel Hill, North Carolina 27599 \\ Correspondence: kmcknigh@email.unc.edu
}

\begin{abstract}
Hepatitis A virus (HAV) is a positive-strand RNA virus classified in the genus Hepatovirus of the family Picornaviridae. It is an ancient virus with a long evolutionary history and multiple features of its capsid structure, genome organization, and replication cycle that distinguish it from other mammalian picornaviruses. HAV proteins are produced by cap-independent translation of a single, long open reading frame under direction of an inefficient, upstream internal ribosome entry site (IRES). Genome replication occurs slowly and is noncytopathic, with transcription likely primed by a uridylated protein primer as in other picornaviruses. Newly produced quasi-enveloped virions (eHAV) are released from cells in a nonlytic fashion in a unique process mediated by interactions of capsid proteins with components of the host cell endosomal sorting complexes required for transport (ESCRT) system.
\end{abstract}

$F^{o l}$

ollowing discovery of the hepatitis A virus AV) particle in human fecal material using immunoelectron microscopy in 1973 (Feinstone et al. 1973), there was considerable controversy concerning the nature of the HAV genome and classification of the virus. This was resolved by the molecular cloning of the genome in the 1980s (Ticehurst et al. 1983; Najarian et al. 1985), which confirmed that it was RNA and placed classification of the virus squarely within the picornavirus family (Picornaviridae). Early studies supported its inclusion within the Enterovirus genus (Gust et al. 1983), but as evidence distinguishing it from other picornaviruses continued to accumulate it was classified within a new genus, Hepatovirus (King et al. 2012). Recent studies have revealed that HAV is evolutionarily distinct from other picornaviruses, not only in terms of the nucleotide sequence of its genome, but also in the structure of its capsid, which shares features in common with primitive insect viruses (Wang et al. 2015; Stuart et al. 2018). Although for many years only humans and other primate species were thought to be susceptible to infection by hepatoviruses, multiple distinct hepatovirus species closely related to human HAV have been recognized recently in various species of small mammals and are now classified within the same genus (Anthony et al. 2015; Drexler et al. 2015; Yu et al. 2016; Sander et al. 2018). These relatively recent insights have led to the realization that HAV is a truly ancient virus with a long association with a range of mammals.

In contrast to many other picornaviruses, including the well-studied poliovirus, HAV

Editors: Stanley M. Lemon and Christopher Walker

Additional Perspectives on Enteric Hepatitis Viruses available at www.perspectivesinmedicine.org

Copyright (C) 2018 Cold Spring Harbor Laboratory Press; all rights reserved; doi: 10.1101/cshperspect.a033480

Cite this article as Cold Spring Harb Perspect Med 2018;8:a033480 
does not shut down cellular protein synthesis in infected cells, and generally replicates without cytopathic effect (Provost et al. 1981; Binn et al. 1984; Gauss-Muller and Deinhardt 1984). One of the most interesting features of the virus is its recently recognized capacity for nonlytic release from infected cells as membranewrapped, quasi-enveloped infectious virions (eHAV) (Fig. 1) (Feng et al. 2013). eHAV particles have a specific infectivity similar to that of the naked virion, and represent a second form of infectious virus. Their mechanism of biogenesis appears to be unique among the $P i$ cornaviridae.

Given the public health threat posed by HAV infection, the main driver for HAV research following discovery of the virus was the need for a safe and efficacious vaccine. With proof that inactivated vaccines could be produced from infected cell cultures (Binn et al. 1988), and that commercially produced vaccines were highly protective against hepatitis A (Werzberger et al. 1992; Innis et al. 1994; Shouval 2018), interest in HAV research waned substantially. This interest has been rekindled in recent years by the discovery of quasi-enveloped virus and a deepening appreciation of the differences that exist between HAV and other mammalian picornaviruses (Feng et al. 2013; Drexler et al. 2015; Wang et al.2015). However, much of what is known (or suspected) of the molecular mechanisms involved in HAV replication rests heavily on studies of other picornaviruses.
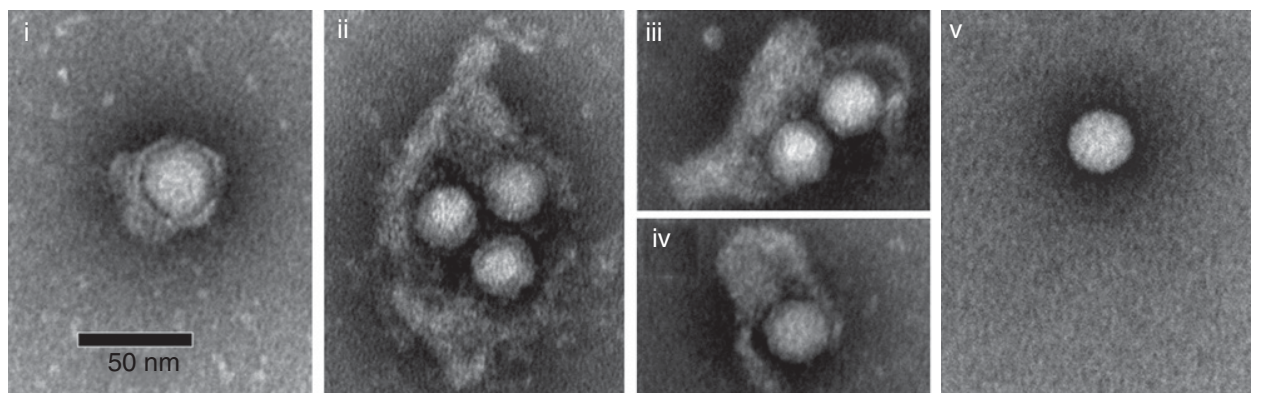

Figure 1. Quasi-enveloped and naked, nonenveloped hepatitis A virus (HAV) virions. Electron microscopic images of negatively stained quasi-enveloped virions (eHAV) (panels i-iv) and naked, $27 \mathrm{~nm}$ nonenveloped ( panel v) virions recovered from supernatant fluids of infected Huh-7.5 cells. (From Feng et al. 2013; adapted, with permission.) 
1993; Schultz et al. 1996b; Yi and Lemon 2002). Continued passage of the virus in cell culture also leads to its attenuation in primates (Provost et al. 1983; Lemon et al. 1990; Funkhouser et al. 1994; Emerson et al. 2002). Although this raised early hopes for development of an oral, Sabin poliovirus-like attenuated hepatitis A vaccine, later studies showing that attenuation of HAV pathogenicity was associated with an unacceptable loss of immunogenicity led to this approach being abandoned (Midthun et al. 1991). Very highly passaged, rapidly replicating, cytopathic variants of HAV have been isolated that induce apoptosis in infected cells (Lemon et al. 1991; Brack et al. 1998). Their virulence has not been assessed in primates, but is likely to be low. The cytopathic effect is linked to enhanced replication capacity, and is associated with multiple mutations throughout the genome (Lemon et al. 1991; Zhang et al. 1995).

Although cytopathic, cell culture-adapted variants such as HM175/18f can be used in classical plaque assays (Zhang et al. 1995), methods for quantifying infectious HAV have generally relied on detection of intracellular viral antigen or RNA. A quantal radioimmunofocus assay (RIFA) was developed in the early 1980s using radioiodinated anti-HAV antibody to demonstrate the presence of replication foci developing beneath an agarose overlay (Lemon et al. 1983). The assay was subsequently adapted for detection of neutralizing anti-HAV antibodies (Lemon and Binn 1983b; Lemon et al. 1997), and more recently modified to use infrared fluorescent anti-HAV probes (Counihan et al. 2006).

\section{GENOME STRUCTURE AND ORGANIZATION}

The HAV genome is a single-stranded, positivesense RNA molecule approximately 7500 nucleotides in length that serves directly as messenger RNA for translation of $\mathrm{HAV}$-encoded proteins (Fig. 2A). It has an exceptionally low $\mathrm{G}+\mathrm{C}$ content compared to other picornaviruses ( $38 \%$ overall) (Cohen et al. 1987b), and a very unusual pattern of codon usage (see Pintó et al. 2018). There is no cap at its $5^{\prime}$ end, which terminates instead in a covalent linkage to a small, virally encoded protein, VPg (or 3B), the putative protein primer for RNA synthesis (Weitz et al. 1986). Like cellular messenger RNAs (mRNAs), the $3^{\prime}$ end terminates in a relatively lengthy poly (A) tail (Baroudy et al. 1985; Najarian et al. 1985).

Multiple strains of human HAV have been molecularly cloned and sequenced, but HM175, a strain recovered in Melbourne, Australia, has been the most intensively studied (Gust et al. 1985; Cohen et al. 1987b). The genome contains a single long open reading frame (ORF) flanked by a relatively lengthy $735 \mathrm{nt} 5^{\prime}$ UTR segment comprising $\sim 10 \%$ of the genome, and a short 63 nt $3^{\prime}$ UTR (Fig. 2A). Both UTRs contain significant RNA secondary structure. The $5^{\prime} \mathrm{UTR}$ fold was established by identifying covariant nucleotide substitutions in several different strains of HAV and mapping sites where singleand double-stranded RNA (dsRNA)-specific nucleases cleave synthetic RNA (Fig. 3A) (Brown et al. 1991a). A small $5^{\prime}$ terminal hairpin is followed by two potential pseudoknots that may function as RNA replication signals, and a short polypyrimidine tract, $\mathrm{pY} 1$, extending from nts 99-138 (Brown et al. 1991a; Hardin et al. 1999). Small deletion mutations in this region of the $5^{\prime}$ UTR confer a temperature-sensitive replication phenotype, but the pY1 tract is not essential for either efficient replication in cultured cells or pathogenicity in primates (Shaffer et al. 1994; Shaffer and Lemon 1995). Its function, if any, is unknown. Further downstream, comprising the $3^{\prime}$ half of the $5^{\prime} \mathrm{UTR}$, are a series of complex structural elements that act as an internal ribosome entry site (IRES) and direct the cap-independent translation of HAV proteins (Fig. 3A).

Secondary RNA structure within the $3^{\prime} \mathrm{UTR}$ (Fig. 3C) has not been as carefully studied, but may be important for binding specific host and/or viral proteins involved in the initiation of minus-strand RNA synthesis (Kusov et al. 1996, 1997). Elsewhere within the genome, located internally within the ORF, is a large complex stem-loop that functions as a cis-acting replication element ( $\mathrm{cre}$ ) that is essential for viral RNA synthesis (Fig. 3B) (Yang et al. 2008). 
A

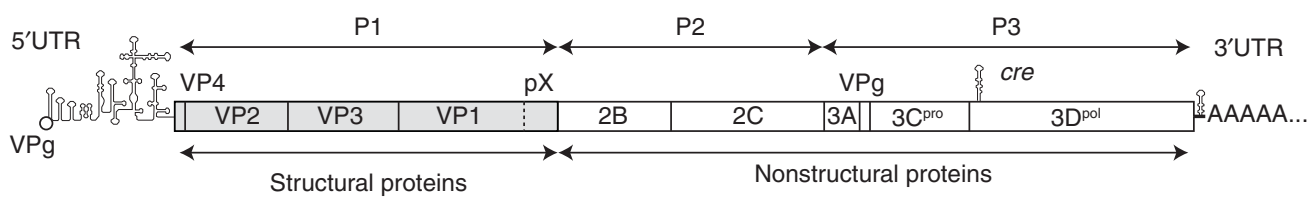

B

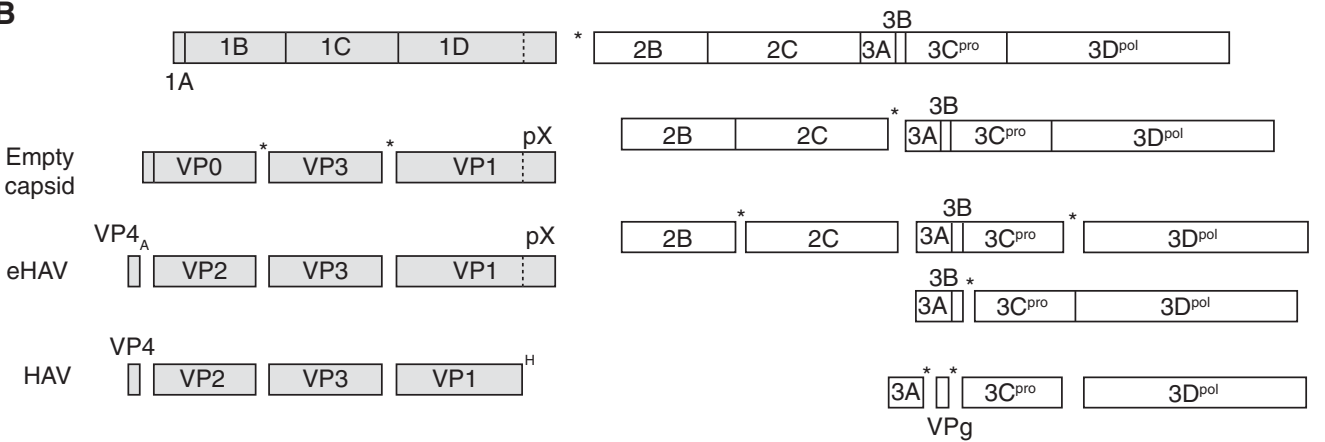

Figure 2. Organization of the hepatitis A virus (HAV) RNA genome and processing of the polyprotein. $(A)$ Genome organization, showing the $5^{\prime}$ covalently-linked VPg (3B) protein, $5^{\prime}$ untranslated region ( $\left.5^{\prime} \mathrm{UTR}\right)$, the internal ribosome entry site (IRES), cre, $3^{\prime} \mathrm{UTR}$, and $3^{\prime}$ poly(A) tail. The open reading frame (ORF) encoding the polyprotein is shown as a box, with cleavage sites leading to production of mature structural ( $\mathrm{P} 1$ segment, $1 \mathrm{~A}-1 \mathrm{D}$, shaded) and nonstructural (P23 segment, 2B-3D, open) proteins. (B) Polyprotein processing. The primary cleavage between VP1pX (1D) and 2B is likely to occur cotranslationally. Processing of the nonstructural proteins results in multiple processing intermediates. The kinetics are not known in detail, but cleavages between $2 \mathrm{~B}$ and 2C, and 3C and 3D appear to be favored (Martin and Lemon 2002). Most scission events are mediated by the $3 \mathrm{C}^{\text {pro }}$ cysteine proteinase (“*”). Exceptions are the VP4-VP2 cleavage, which is autocatalytic (“A”) and activated by packaging of the RNA genome, and excision of the pX domain from VP1pX after loss of the quasi-enveloped virion (eHAV) membrane, which is mediated by an unknown host protease (" $\mathrm{H}$ ").

\section{POLYPROTEIN PROCESSING}

The large ORF encodes a single $\sim 2230$ amino acid polyprotein that is processed into 10 mature proteins primarily by a single virally encoded proteinase, 3C $\mathrm{C}^{\text {pro }}$ (Fig. 2B) (Schultheiss et al. 1994; Gosert et al. 1996; Martin and Lemon 2002). Three large structural proteins are produced from the amino terminal P1 segment of the polyprotein: VP0, VP3, and VP1pX. These are alternatively referred to as $1 \mathrm{AB}, 1 \mathrm{C}$, and $1 \mathrm{D}$, according to a well-established, systematic nomenclature for picornaviruses (Rueckert and Wimmer 1984). Sixty copies of each of these assemble to form the viral capsid, with VP0 $(1 \mathrm{AB})$ undergoing a maturation cleavage resulting in VP4 (1A) and VP2 (1B) (Fig. 2B) following packaging of the RNA genome. VP1pX is the largest of the structural proteins, $38.5 \mathrm{kDa}$ in mass, and is found in early morphogenesis intermediates and in eHAV released from cells (Anderson and Ross 1990; Feng et al. 2013). An $8.3 \mathrm{kDa}$ fragment ("pX") is cleaved from the carboxy terminus of VP1pX by an unknown cellular protease (Fig. 2B) following disruption of the eHAV membrane (Graff et al. 1999; Martin et al. 1999; Feng et al. 2013), resulting in the mature $31.2 \mathrm{kDa}$ VP1 protein found in naked, nonenveloped virions excreted from infected animals and humans. The VP1-pX cleavage is efficient, but leaves VP1 with a heterogeneous carboxyl terminus (Graff et al. 1999).

The primary cleavage event in polyprotein processing occurs between VP1pX (1D) and 2B (Fig. 2B) and has been a source of confusion in the field as early, inaccurate annotations of genome sequences have persisted in on-line databases. In contrast to most other picornaviruses, 
HAV Replication Strategy

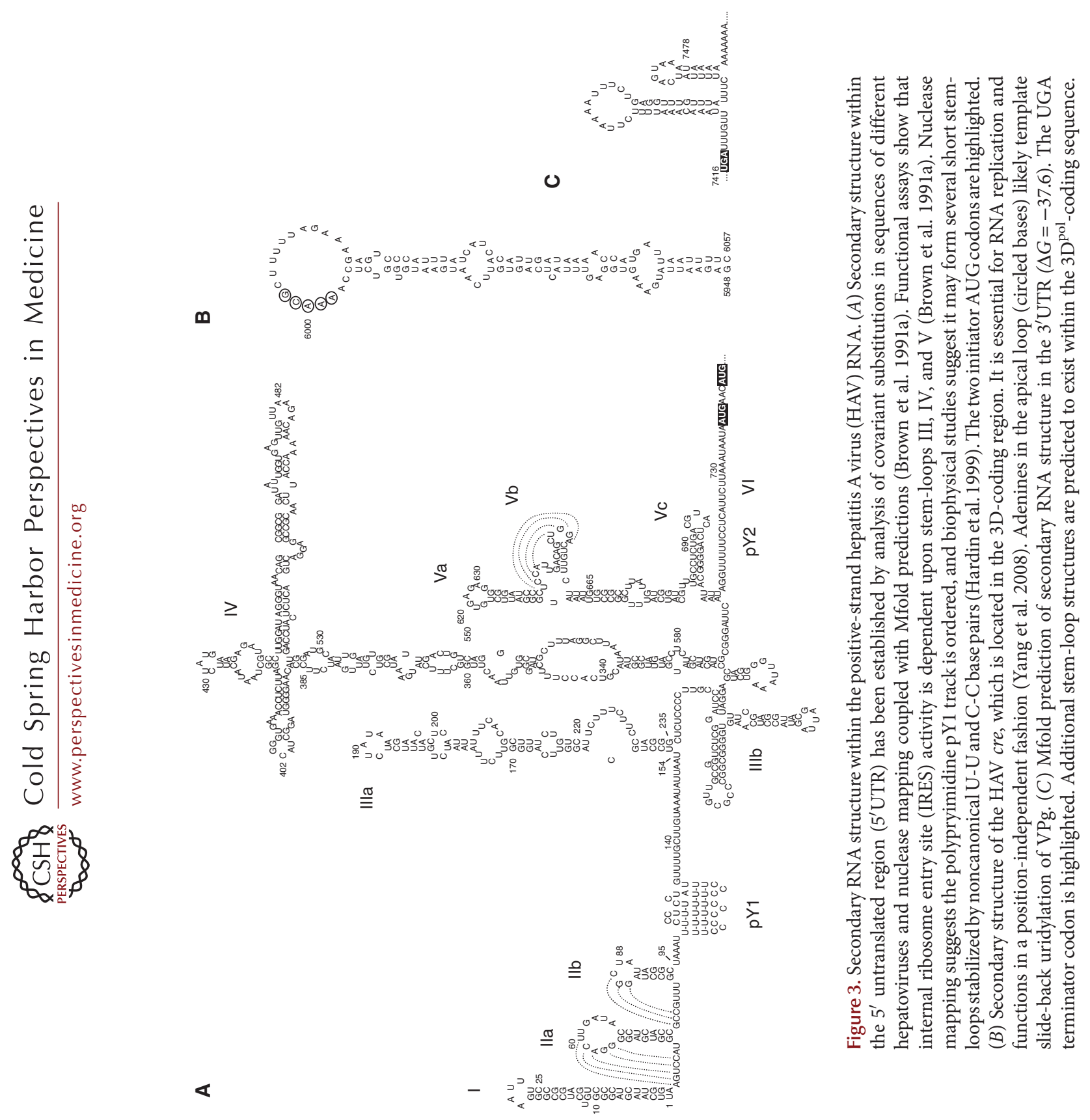


HAV lacks a nonstructural 2A protein, which is a proteinase in enteroviruses that cleaves structural protein precursors (the "P1" segment) from the remainder of the polyprotein, and an autocatalytic polypeptide in aphthoviruses and cardioviruses that serves a similar function (Martin and Lemon 2002). The carboxy-terminal $8 \mathrm{kDa}$ pX fragment of VP1pX has often been referred to as " $2 \mathrm{~A}$," but it is a structural protein with major roles in capsid assembly (Harmon et al. 1995; Martin et al. 1995) and (in unpublished work from our laboratory) quasi-envelopment of the capsid. Mutations in pX have been shown to influence virulence in tamarins, which additionally points to its critical involvement in pathogenesis (Harmon et al. 1995; Emerson et al. 2002).

Six nonstructural proteins, each involved in replication of the HAV RNA, are derived from the remaining $\mathrm{P} 2$ and $\mathrm{P} 3$ segments of the polyprotein: $2 \mathrm{~B}, 2 \mathrm{C}, 3 \mathrm{~A}, 3 \mathrm{~B}, 3 \mathrm{C}^{\mathrm{pro}}$, and $3 \mathrm{D}^{\mathrm{pol}}$ (Fig. $2 \mathrm{~B})$. These proteins are all intimately associated with membranes (Jecht et al. 1998). Like other picornaviruses, the $2 \mathrm{C}$ protein contains a helicase motif and, when overexpressed (with or without $2 \mathrm{~B}$ as $2 \mathrm{BC}$ ), induces substantial membrane rearrangements in cells (Teterina et al. 1997). The 3A protein provides a membrane anchor for 3B (Pisani et al. 1995), the genomelinked protein (VPg) that likely serves as a protein primer for RNA synthesis. Interestingly, 3A is targeted to mitochondrial membranes (Yang et al. 2007). $3 C^{\text {pro }}$ is a cysteine protease, albeit with a fold similar to the serine protease chymotrypsin, and was one of the first viral proteases to be characterized structurally (Chernaia et al. 1993; Allaire et al. 1994). The 3ABC processing intermediate is unique among picornaviruses in that it is relatively stable and has distinct activities in particle assembly (Probst et al. 1998) as well as disruption of innate immunity (Yang et al. 2007; Feng and Lemon 2018). 3D ${ }^{\text {pol }}$ is the viral RNA-dependent RNA polymerase and the catalytic core of the replicase complex, but unlike the poliovirus polymerase, has never been expressed in active form (Tesar et al. 1994). Processing at the $3 \mathrm{CD}$ site is more efficient than at $3 \mathrm{AB}$ and $3 \mathrm{BC}$, but like $3 \mathrm{ABC}, 3 \mathrm{CD}$ is proteolytically active and contributes to disruption of in- nate immunity (Probst et al. 1998; Qu et al 2011).

\section{VIRION STRUCTURE}

\section{Nonenveloped, “Naked” HAV Virions}

Although naked HAV virions have a composition similar to other picornaviral capsids, with 60 copies of each of the four mature capsid proteins (VP4, VP2, VP3, and VP1) arranged in a pseudo $T=3$ symmetry, the HAV capsid has numerous distinguishing features (Wang et al. 2015; Stuart et al. 2018). Morphogenesis begins with the formation of protomers composed of VP0, VP3, and VP1 that assemble into 14 S pentamer subunits that share partial antigenicity with the mature icosahedral capsid (Stapleton et al. 1993). In other picornaviruses, VP4 is amino-terminally myristoylated and serves to nucleate the assembly of pentamers. This is not the case in HAV, in which VP4 has a much smaller molecular mass and is not myristoylated (Tesar et al. 1993). Pentamer assembly is driven instead by intrinsic signals in the amino terminal half of the pX domain in VP1pX, whereas VP4 appears essential for further assembly of pentamers into $70 \mathrm{~S}$ empty capsids (Probst et al. 1999; Cohen et al. 2002). Empty capsids are abundant in virus preparations, but whether they are intermediates in the assembly of infectious virions is unknown.

As mentioned above, VP0 is cleaved to VP4 and VP2 following packaging of the RNA genome. The packaging mechanism is poorly understood, but studies with enteroviruses suggest a key role for the $2 \mathrm{C}$ helicase, and RNA-activated autocatalytic processing of VP2 (Jiang et al. 2014a). As in other picornaviruses, VP0 cleavage is associated with an increase in specific infectivity and likely conformational changes in the HAV capsid (Bishop and Anderson 1993). However, it is inefficient and proceeds with slow kinetics in HAV capsids isolated from infected cell cultures.

Mature nonenveloped virus has a sedimentation coefficient of $144 \mathrm{~S}$ and bands in $\mathrm{CsCl}$ at a density of $1.325 \mathrm{gm} / \mathrm{cm}^{3}$, indicating a tight capsid structure (Lemon et al. 1985; Wang et al. 
2015). X-ray crystallography has recently revealed details of the capsid structure at high resolution, including the existence of a unique VP2 domain swap found in no other mammalian picornavirus (Wang et al. 2015; Stuart et al. 2018). The surface of the capsid is relatively featureless: there is no "canyon" surrounding the fivefold axis of symmetry like that into which the enteroviral receptor fits. The HAV capsid is substantially more stable at low $\mathrm{pH}$ and high temperatures than other picornaviruses (Siegl et al. 1984; Scholz et al. 1989).

There is a high degree of antigenic conservation among different strains of human HAV (Lemon and Binn 1983a; Stapleton and Lemon 1987; Ping and Lemon 1992). Important antigenic determinants are conformational in nature, and not recapitulated by independently expressed capsid proteins. Remarkably, the binding of postconvalescent, polyclonal human antibodies to the virus can be blocked almost completely by a combination of only two monoclonal antibodies (Ping and Lemon 1992). Neutralization epitopes map to one large cluster, with substitutions at residue 70 of VP3 dominating selection of monoclonal antibody escape mutants (Ping and Lemon 1992). However, more recent studies have expanded the range of capsid residues contributing to antigenic sites (Wang et al. 2015). The antigenic conservation of the HAV capsid extends to distantly related hepatoviruses identified recently in bats, which bind monoclonal antibodies raised to human HAV (Drexler et al. 2015).

\section{Quasi-Enveloped eHAV Virions}

Although naked, nonenveloped virions are shed in the feces of infected humans and nonhuman primates, only quasi-enveloped eHAV virus is detected in serum (Feng et al. 2013). The available evidence suggests that eHAV is secreted across the apical plasma membrane of hepatocytes into the proximal biliary canaliculi, where the membrane is stripped from the capsid by the detergent action of bile salts (Hirai-Yuki et al. 2016b). Most virions present in supernatant fluids of infected cell cultures are also quasi-envel- oped (Feng et al. 2013; Hirai-Yuki et al. 2016b; Das et al. 2017).

Quasi-enveloped eHAV virions are between 50 and $110 \mathrm{~nm}$ in diameter and have a buoyant density of $\sim 1.10 \mathrm{gm} / \mathrm{cm}^{3}$ in iodixonal, in contrast to naked virions that are $\sim 27 \mathrm{~nm}$ in diameter and band in iodixanol at a buoyant density of $\sim 1.25 \mathrm{gm} / \mathrm{cm}^{3}$ (Feng et al. 2013). Electron microscopy of negatively stained eHAV preparations show membranous vesicles containing one or two, occasionally three, RNA-containing capsids (Fig. 1). As mentioned above, these capsids contain predominantly unprocessed VP1pX, rather than the mature VP1 found in mature naked virions (Fig. 2B). The enveloping membranes completely occlude the capsid, preventing detection of capsid antigen in the absence of detergents and protecting it from antibody-mediated neutralization (Feng et al. 2013). Quasi-enveloped virions resemble exosomes and present no viral glycoproteins (peplomers) on the membrane surface, a feature that distinguishes them from conventional enveloped viruses (Feng et al. 2014). Yet, their specific infectivity is similar in cultured cells to that of naked virions (Feng et al. 2013). Consistent with the lipid membranes that cloak these virions, eHAV infectivity is lost upon extraction with organic solvents such as chloroform.

A recent quantitative proteomics analysis using stable isotope labeling with $\left[{ }^{13} \mathrm{C}\right]$ and $\left[{ }^{12} \mathrm{C}\right]$ (SILAC) followed by tandem mass spectrometry (MS/MS) identified 105 host proteins that were enriched in gradient-purified eHAV compared to unrelated extracellular vesicles banding at a similar density in iodixanol gradients (McKnight et al. 2017). The eHAV-associated proteins were highly enriched for endolysosomal components $(>60 \%, p<0.001)$ and included many common exosome-associated proteins, such as the tetraspanin CD9 and dipeptidyl peptidase 4 (DPP4) as well as multiple proteins associated with the endosomal sorting complexes required for transport complex III (ESCRT-III), including charged multivesicular body protein (CHMP)1A/1B, CHMP4B, IST, and apoptosis-linked gene 2-interacting protein $\mathrm{X}$ (ALIX). eHAV biogenesis is discussed below. Importantly, antibodies to ALIX and DPP4 pre- 
K.L. McKnight and S.M. Lemon

cipitate eHAV present in serum from infected humans (McKnight et al. 2017).

\section{THE HAV REPLICATION CYCLE}

\section{Cell Entry}

Quasi-envelopment has important implications for cellular entry of the virus. Although infection typically results from ingestion of naked, nonenveloped virions, it is not clear which cell types are first infected, or even whether there is a primary site of replication within the gut (Mathiesen et al. 1978; Asher et al. 1995). On the other hand, once infected, spread of the virus within the host appears to involve quasi-enveloped virus, as only eHAV is detected in serum or plasma during acute infection (Feng et al. 2013). The mechanism by which eHAV enters cells must a priori differ from that of the naked virion, although it seems likely that they might share later steps in the entry process, such as interactions of the capsid with a specific cellular receptor. Such receptor interactions are central to the entry and uncoating of other picornaviruses, as well as delivery of their RNA genomes across endosomal membranes (Strauss et al. 2015).

T-cell immunoglobulin and mucin domaincontaining protein 1 (TIM1) is a phosphotidylserine (PtdSer) receptor involved in scavenging of apoptotic cells, and it facilitates the attachment and entry of many enveloped viruses that display PtdSer on their surface (Moller-Tank et al. 2013). It was reported to be an essential receptor for HAV in 1996, and has otherwise become known as "HAV cellular receptor 1 protein” (HAVCR1) (Kaplan et al. 1996; Feigelstock et al. 1998). However, recent studies show TIM1 is not an essential entry factor for HAV. Clustered regularly interspaced short palindromic repeats (CRISPR)/Cas9-mediated TIM1 knockout does not impair the ability of quasi-enveloped eHAV or HAV to infect Huh-7.5 human hepatoma cells (Das et al. 2017). TIM1 does seem to play a minor role in facilitating eHAV entry in Vero cells, most likely by binding PtdSer residues present on the surface of the eHAV membrane (Feng et al. 2015; Das et al. 2017). However, Tim $1^{-/-}$Ifnar $1^{-/-}$double-knockout mice are susceptible to infection on intravenous virus challenge, with only modest reductions in fecal HAV shedding and serum alanine aminotransferase (ALT) elevations compared to Ifnar $1^{-/-}$mice (Das et al. 2017). These recent results point to a large gap in our understanding of HAV biology. Most studies investigating cellular entry of the virus were done prior to the recognition of quasi-enveloped eHAV, and in retrospect the nature of the virus inoculum used in these studies is often uncertain.

The initial uptake of eHAV into cells is likely to occur by mechanisms similar to those by which cells internalize exosomes. Unfortunately, these remain poorly understood. Clathrinmediated endocytosis, macropinocytosis, and phagocytosis have all been implicated (Feng et al. 2010; Tian et al. 2014; van Dongen et al. 2016). PtdSer residues and adhesion molecules (integrins and tetraspanins) on exosome membranes contribute to the uptake of exosomes (Clayton et al. 2004; Hoshino et al. 2015; van Dongen et al. 2016), and PtdSer exists on the eHAV surface and promotes its efficient uptake by plasmacytoid dendritic cells (Feng et al. 2015). Integrin- $\beta 3$ and the tetraspanins CD9 and CD63 are also associated with the eHAV membrane (McKnight et al. 2017).

eHAV has been shown to enter cells via an endocytic pathway with slow removal of its enveloping membrane rendering the capsid subject to neutralization by antibody in an endosomal compartment, even when antibody is added to cell cultures 6-8 h after removal of an eHAV inoculum (Feng et al. 2013; Das et al. 2017). The naked virion enters more rapidly, and is not subject to postendocytic neutralization. The lysosomal poison, chloroquine, strongly inhibits eHAV entry, and has much less effect on entry of naked HAV virions (Feng et al. 2013). It seems likely that endocytosed eHAV undergoes transport to a late endosome/lysosomal compartment where its membranes are degraded by lysosomal enzymes, providing the capsid access to a cellular receptor. A similar entry scheme has recently been suggested for quasi-enveloped hepatitis $\mathrm{E}$ virus (eHEV) (Yin et al. 2016). Naked HAV may interact with the same receptor, but in an early 
endosome. Specific mechanisms of endocytosis of the two types of virions remain to be established.

\section{Uncoating of the Genome}

The final step in picornaviral entry is delivery of the RNA genome across the endosomal membrane to the cytosol. Early studies demonstrated that uncoating of HAV proceeds in a slow and asynchronous fashion (Bishop and Anderson 2000). Enteroviral capsids deliver their genomes to the cytosol via an "umbilicus" leading to a membrane pore formed by the myristoylated VP4 protein and the amino terminus of VP1 that extends from the capsid upon receptor binding (Strauss et al. 2013; Panjwani et al. 2014). VP4 may contribute to a similar process in HAV entry, even though it is not myristoylated (Tesar et al. 1993), as it appears to have direct membrane pore-forming activity (Shukla et al. 2014). However, the absence of any apparent receptor interaction site in the recently solved X-ray structure of the HAV capsid has fueled speculation that the virus may enter and uncoat by a mechanism completely different from other picornaviruses, with the capsid possibly entering the cytosol intact and uncoating intracellularly (Wang et al. 2015).

\section{Viral Protein Translation}

Once HAV RNA has been delivered to the cytosol, the replication cycle commences with protein translation to produce both structural proteins as well as the nonstructural proteins necessary for establishing an RNA replication complex. VPg is likely removed from the genomic RNA soon after its arrival in the cytosol, and translation of the polyprotein is initiated in a $5^{\prime}$ cap-independent fashion under control of the IRES, which is comprised of stem-loops III, IV, and V (Fig. 3A) of the 5'UTR (Brown et al. 1994). The highly ordered RNA structure of the IRES functions in association with canonical host-cell translation initiation factors and various accessory proteins (Brown et al. 1991a,b; Glass et al. 1993). 40S ribosome subunits appear likely to land on the viral genome close to or at the initiation codon, with little if any $5^{\prime}$ to $3^{\prime}$ scanning on the RNA. Translation initiates at one of two closely spaced AUG initiator codons, resulting in a heterogeneous amino-terminal VP4 sequence (Tesar et al. 1992).

The HAV IRES is a type III IRES (Brown et al. 1994; Beales et al. 2003), differing significantly in its structure (Fig. 3A) from other picornaviral IRES elements, and it is relatively inefficient in directing translation in cultured cells (Whetter et al. 1994). It requires intact cellular eIF4G to initiate translation (Borman and Kean 1997; Ali et al. 2001), which distinguishes it from the IRES elements of enteroviruses or aphthoviruses that encode proteases that shut down cellular mRNA translation by cleaving this host translation initiation factor. HAV does not shut down host mRNA translation, which proceeds in parallel with viral translation (Gauss-Muller and Deinhardt 1984).

Cell culture-adaptive mutations within the HAV IRES contribute to enhanced replication and cell-type-specific translation efficiency (Day et al. 1992; Schultz et al. 1996a). Poly(rC)-binding protein 2 ( $\mathrm{PCBP} 2)$, polypyrimidine-tractbinding protein (PTB), and La protein, as well as GAPDH, which binds the RNA specifically, have all been found to positively or negatively regulate IRES activity (Chang et al. 1993; Graff et al. 1998; Gosert et al. 2000a; Yi et al. 2000; Jiang et al. 2014b). The relatively weak activity of the HAV IRES coupled with suboptimal codon bias throughout the ORF contribute to slow and inefficient translation (Whetter et al. 1994; Pintó et al. 2007, 2018), an HAV attribute that may have evolved to reduce cytopathology in the liver and/or facilitate folding of the very stable capsid. $3 C^{\text {pro }}$-mediated processing of the polyprotein, as outlined above (Fig. 2B), probably commences simultaneously with translation as soon as the proteinase is expressed.

\section{Viral RNA Synthesis}

Picornaviruses usurp cellular proteins and membranes to establish membranous replication factories that are essentially mini-organelles. The membranes likely protect viral replication intermediates from being sensed by 
cytoplasmic pathogen recognition receptors such as the RIG-I-like helicases, and also provide a platform for assembly of a multiprotein replication complex. Ectopic expression of the HAV 2BC and 2C proteins induces cytoplasmic membrane rearrangements as well as increases in membrane permeability (Teterina et al. 1997; Jecht et al. 1998; Kusov et al. 1998; Gosert et al. 2000b). Thus, as with other picornaviruses, $2 \mathrm{~B}$ and $2 \mathrm{C}$ appear to cooperatively orchestrate the redirection of intracellular membranes to the formation of replication complexes. These membranes are likely derived from the endoplasmic reticulum, although it is interesting that $3 \mathrm{~A}$, which anchors $3 \mathrm{ABC}$ to membranes, has a transmembrane domain that targets its delivery to mitochondrial membranes (Pisani et al. 1995; Ciervo et al. 1998; Yang et al. 2007). Replication complexes, identified by staining with antibodies specific for dsRNA, lie in close proximity to both mitochondria and ER. Host factors are clearly involved in establishing and maintaining these HAV replication factories, but have not been extensively studied. Recent studies demonstrate the dependence of RNA replication on adenosine-triphosphate-binding cassette transporters and FK506-binding proteins (Esser-Nobis et al. 2015). Unlike the membranous replication complexes of $\mathrm{HCV}$, also a positive-strand RNA virus, HAV replication complexes are not dependent upon host phosphatidylinositol 4-kinase III $\alpha / \beta$ (PI4K III $\alpha / \beta)$. HAV RNA synthesis can be inhibited by guanidine as well as cyclosporine A (Cho and Ehrenfeld 1991; Esser-Nobis et al. 2015).

HAV probably uses the same strategy as other picornaviruses to synthesize new genomes (Fig. 4). A minus-strand copy of the incoming positive-strand genome is first made, and the resulting dsRNA intermediate is then used as a template to produce new positive-strand genomes. Minus-strand RNA is of low abundance and difficult to detect in infected cells (Schmitz and Dotzauer 1998). The $3 \mathrm{D}^{\mathrm{pol}}$ polymerase is the catalytic core of the replication complex, with minus-strand RNA synthesis likely primed by a uridylated form of VPg (3B, VPg-pUpU) binding to the genomic $3^{\prime} \operatorname{poly}(\mathrm{A})$ sequence (Fig. 4 inset). Poliovirus VPg is uridylated via a slide-back mechanism by a complex of $3 \mathrm{D}^{\text {pol }}$ and $3 \mathrm{CD}$ interacting with the adenine residues in the poliovirus cre (Paul et al. 2003). The HAV cre (Fig. 3B), located within the 3D-coding region of the ORF (Fig. 2A), has a similar arrangement of adenines within its terminal loop and functions in a position-independent fashion (Yang et al. 2008), which suggests a similar mechanism for uridylation. The $3^{\prime} \mathrm{UTR}$ likely adopts secondary structure (Fig. 3C) that scaffolds the binding and engagement of viral proteins necessary for initiating RNA replication (Fig. 3) (Nuesch et al. 1993; Kusov et al. 1996). However, this has not been studied in detail.

Positive-strand RNA synthesis is similarly primed by VPg-pUpU, explaining the presence of VPg at the $5^{\prime}$ end of positive-strand viral RNA (Weitz et al. 1986). Secondary RNA structure within stem-loops I-II of the $5^{\prime} \mathrm{UTR}$, upstream of the viral IRES (Fig. 3A), may act in coordination with viral proteins to melt the end of the newly formed duplex dsRNA such that VPgpUpU can anneal to the $3^{\prime}$ end of the minusstrand template to prime positive-strand synthesis, but these potential RNA replication signals have not been studied in detail. Poliovirus minusand positive-strand RNA synthesis, and the inherent conflict between the $5^{\prime}$ to $3^{\prime}$ movement of ribosomes and $3^{\prime}$ to $5^{\prime}$ translocation of the replicase on the positive-strand genome, are tightly regulated by key interactions between viral and host cell RNA-binding proteins (Ogram and Flanegan 2011). HAV replication is no doubt similarly regulated, but this remains largely a black box. Multiple viral and cellular proteins bind the HAV 5'UTR with specificity (Chang et al. 1993; Schultz et al. 1996a; Graff et al. 1998; Beneduce et al. 1999), but their involvement in replication of the RNA has yet to be determined.

\section{Virion Assembly}

Little is known about how HAV capsid assembly (see above) and packaging of the viral RNA proceeds within infected cells. A role for the helicase activity of poliovirus $2 \mathrm{C}$ has been established recently in packaging of the poliovirus genome (Jiang et al. 2014a). The HAV 2C sequence suggests it also possesses helicase activity, and it is likely 


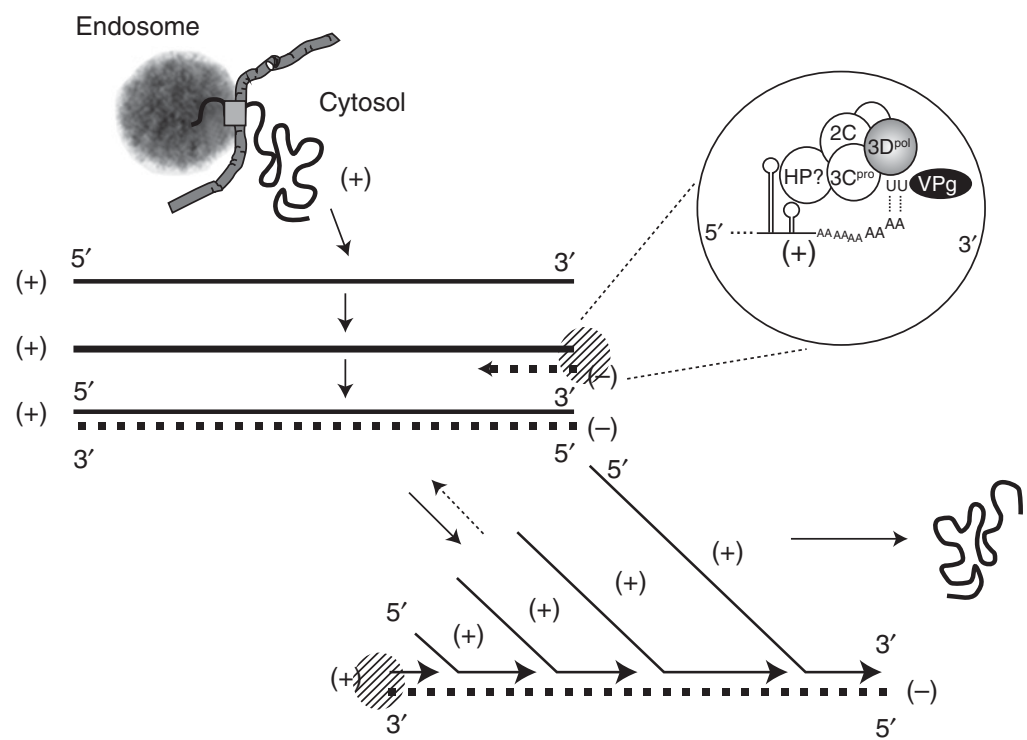

Figure 4. RNA replication. Picornaviral replication is nonconservative, with more positive-strand RNA (+, solid line) than minus-strand RNA (-, dashed line) synthesized. The process begins after delivery of the (+)-strand genome to the cytosol and internal ribosome entry site (IRES)-directed translation has produced the nonstructural proteins required for replicase assembly. The incoming (+)-strand serves as template for initial synthesis of a (-)-strand, resulting in a full-length duplex double-stranded RNA (dsRNA). 3D ${ }^{\text {pol }}$ catalyzes RNA synthesis, but other viral and host proteins (HPs) are likely to be required for transcription. In a second step, the $5^{\prime}$ end of the $(+)$-strand dissociates from the (-)-strand in the duplex, allowing priming for synthesis of a new (+)-strand, a process that then repeats. Little if any single-stranded (-)-strand RNA is produced. Uridylated VPg-pUpU serves as the protein primer for both $(-)$-strand and $(+)$-strand synthesis in tightly coupled reactions, annealing with terminal adenines at the $3^{\prime}$ ends of both (+)-strand (see inset) and (-)-strand RNA. New (+)-strand RNA molecules are either packaged into nascent capsids, or recycled as a template for more (-)-strand synthesis.

to play a similar role in packaging. Confocal microscopy shows that mature HAV capsid and dsRNA colocalize at foci within infected cells, suggesting that virion maturation occurs close to sites of RNA replication (Fig. 5). However, extensive spatial segregation of capsid and RNA replication intermediates is also evident. In part, this may reflect the rapid recruitment of fully formed capsids to endosomes for export from the cell, as described in the following section.

\section{Quasi-Envelopment and Viral Egress}

Although minor amounts of naked HAV can be found in the supernatant fluids of infected cell cultures, this likely represents nonspecific release of virus through cell death or possibly loss of the membrane from secreted eHAV virions. Egress of newly replicated infectious virus is predominantly nonlytic (Feng et al. 2013). Although not visualized directly, HAV capsids appear to be recruited to endosomes via interactions with components of the ESCRT system, budding into endosomes to form multivesicular bodies (MVBs) destined for transport to the plasma membrane where membrane fusion leads to the release of capsids wrapped within a single membrane (Fig. 6).

MVBs are formed by three distinct ESCRT protein complexes, acting sequentially to sort and load cellular cargo destined for degradation in lysosomes or export from the cell (Hurley 2015). ESCRT-I and ESCRT-II are core ESCRT machinery that sequester cargo at the endosomal membrane, often recognizing cargo as a result of its ubiquitylation, thereby creating an inward bud (Hurley 2015). ESCRT-III oligomers are recruited and pinch the neck of the 


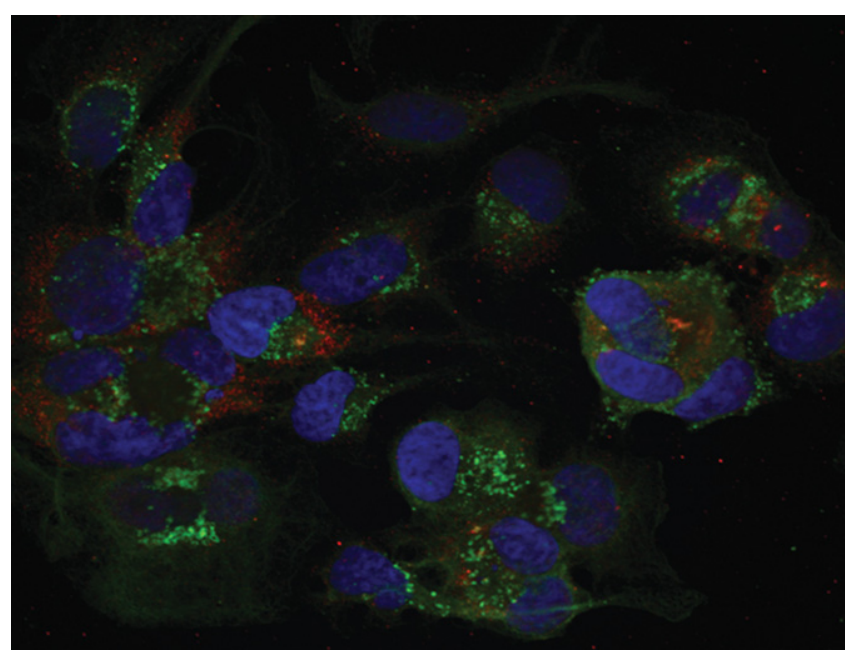

Figure 5. Confocal fluorescence microscopy showing viral RNA and capsid proteins in hepatitis A virus (HAV)infected cells. Huh-7.5 cells were fixed on chamber slides at 14-days posttransfection of infectious HM175/p16 synthetic RNA. Double-stranded RNA (dsRNA) (red) was visualized by staining with a specific monoclonal antibody J2 (Scicons), and conformational HAV capsid antigen (green) by staining with JC serum (Feng et al. 2013). Most cells show foci where the two signals colocalize, but there is extensive segregation of dsRNA (RNA synthesis) and capsid antigen (assembled capsids). Nuclei have been counterstained with DAPI (blue).

membrane invagination, releasing the buds into the endosomal lumen as intralumenal vesicles (ILVs) to form MVBs (Fig. 6). In later steps, VPS4 acts to dissociate the ESCRT-III oligomers. MVBs may then fuse with lysosomes for degradation of their cargo, or be directed to the plasma membrane where fusion releases ILVs as extracellular exosomes (Mathivanan et al. 2010; Bobrie et al. 2011).

ALIX, also known as programmed cell death 6 interacting protein (PCD6IP), is an accessory ESCRT protein that feeds into ESCRTIII complexes in parallel with ESCRT-I/II, and interactions with it represent a second pathway for cargo selection (Hurley 2015). HAV has hijacked this pathway to exit the cell, as RNAimediated knockdown of ALIX, CHMP2A (ESCRT-III), or VPS4B strongly inhibit eHAV release (Feng et al. 2013; McKnight et al. 2017). ALIX, VPS4, and several CHMP proteins are physically associated with extracellular eHAV, as noted above.

Two distinct, possibly redundant sorting signals appear to be involved in the recruitment of HAV capsids by the ESCRT system. Structural proteins of conventional enveloped viruses con- tain "late domains" (PPXY, P(S/T)AP, GPPX 3 Y, or $\left.\mathrm{YPX}_{1 \text { or } 3} \mathrm{~L}\right)$ that mediate interactions with ESCRT machinery (Ren and Hurley 2011). Two tandem $\mathrm{YPX}_{3} \mathrm{~L}$ motifs, separated by 28 residues in the HAV VP2 capsid protein, are the only such motifs in the HAV polyprotein, and are conserved in all 94 human HAV sequences in GenBank as well as 10 novel hepatovirus species recently identified in bats and other small mammals (Feng et al. 2013; Drexler et al. 2015). $\mathrm{YPX}_{3} \mathrm{~L}$ motifs mediate interactions with ALIX, which in turn binds CHMP4 (ESCRT-III) in a step critical for membrane scission (Hurley 2010). Both CHMP4 and ALIX are present in eHAV, and anti-ALIX antibodies precipitate the HAV capsid in a $\mathrm{YPX}_{3} \mathrm{~L}$ motif-dependent manner (Feng et al. 2013; McKnight et al. 2017). Paradoxically, however, recent crystallographic studies of the naked HAV capsid show that both $\mathrm{YPX}_{3} \mathrm{~L}$ motifs are partially buried beneath the surface (Wang et al. 2015; Stuart et al. 2018), where the motifs are unlikely to be accessible for binding by ALIX. These contradictory findings have yet to be reconciled, but it may be that the conformation of the capsid is different within eHAV (where unprocessed VP1pX 


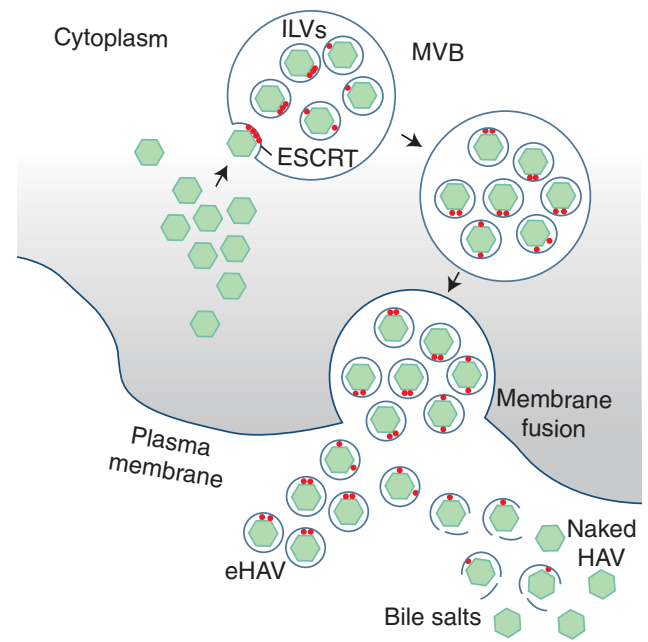

Figure 6. Biogenesis of extracellular quasi-enveloped (eHAV) and nonenveloped virions. Following assembly and packaging of the viral RNA, capsids are recruited to the surface of endosomes through VP2 and VP1pX interactions with components of the endosomal sorting complexes required for transport (ESCRT) system (apoptosis-linked gene 2-interacting protein X [ALIX] and others). Inward budding of the capsids into the endosome results in intraluminal vesicles (ILVs) and formation of multivesicular bodies (MVBs). The MVBs undergo transport to the plasma membrane, where membrane fusion leads to the release of membrane-wrapped eHAV virions to the extracellular space. eHAV virions that are shed from the basolateral hepatocyte membrane into hepatic sinusoids circulate in the blood, whereas eHAV secreted across the apical membrane undergoes conversion to naked, nonenveloped virions mediated by bile salts in the proximal biliary system.

predominates) than in the mature, naked virion, and allows for physical interaction of the motifs with ALIX.

A second signal for quasi-envelopment appears to reside within the $\mathrm{pX}$ domain itself, which shares no sequence identity with any other protein in the database. Unpublished studies from our laboratory show that specific mutations within this domain prevent the release of assembled, infectious capsids from infected cells. The nature of this signal remains under investigation.

Most of the above has been gleaned from studies of infected cell cultures. Confirming details of HAV replication or quasi-envelopment in vivo is not a trivial exercise. However, quasienveloped eHAV is the only form of the virus that can be detected in serum or plasma from acutely infected primates, and gradient-purified membrane-associated virions with the buoyant density of eHAV are infectious for Ifnar $1^{-/}$ mice (Feng et al. 2013; Das et al. 2017).

Hepatocytes are polarized epithelial cells, with apical membranes that abut the proximal biliary canaliculus into which bile salts are secreted, and basolateral membranes facing onto hepatic sinusoids that are bathed continuously by blood. Studies of polarized Caco-2 human colonic carcinoma cells or HepG2-N6 hepatocytes show differences in vectorial release of $\mathrm{HAV}$, with release from Caco-2 cells being almost entirely apical in direction, whereas it is largely basolateral in HepG2-N6 cells (Blank et al. 2000; Snooks et al. 2008). However, most HAV released from either the basolateral or apical surfaces of these cells is quasi-enveloped, and membrane-associated virus has been identified within bile from infected mice (Hirai-Yuki et al. 2016b). eHAV released across the apical surface appears to be stripped of its membranes by the detergent action of bile salts, and this is the primary source of naked virions excreted in feces (Hirai-Yuki et al. 2016a,b). The virus is thus ideally positioned for both spread within the environment (as a highly stable, naked virion), and within the individual infected host (as membrane-cloaked virions that are hidden from the immune system and impervious to antibodymediated neutralization) (Feng et al. 2013).

\section{CONCLUDING THOUGHTS}

The successful deployment of inactivated vaccines for HAV in the mid-1990s resulted in a demonstrable drop in research on this ancient but remarkable pathogen. Research funding and interest in the field shifted to other hepatotropic pathogens, such as hepatitis B virus (HBV) and HCV, which cause chronic liver disease. As a result, numerous important questions remain unanswered today concerning the virus and the disease it causes. However, there has been a reawakening of interest in recent years, fueled largely by discovery of eHAV quasi-envel- 
opment. How HAV manages to evade innate and adaptive immune responses for weeks after initial infection has been answered in part by the discovery of eHAV (Feng et al. 2013), and the role of HAV proteinase precursors in disrupting innate immune responses (Yang et al. 2007; Qu et al. 2011). The discovery of eHAV has also increased appreciation of the potential for nonlytic release of other classically "nonenveloped" viruses, including other picornaviruses (AltanBonnet 2016). A mouse model for hepatitis A now exists with which questions related to pathogenesis can be addressed (Hirai-Yuki et al. 2016a). Numerous distantly related hepatoviruses have been recently discovered in a large number of species of small mammals, providing novel insight into evolution of HAV (Drexler et al. 2015). And, finally, the structure of the HAV capsid has been solved using X-ray crystallography (Wang et al. 2015), information that ultimately can be used to answer questions about antigenicity, neutralization, and possibly why the HAV vaccine is so successful. With only a small research effort, big gains have been made and continued interest in HAV research seems assured.

\section{REFERENCES}

${ }^{*}$ Reference is also in this collection.

Ali IK, McKendrick L, Morley SJ, Jackson RJ. 2001. Activity of the hepatitis A virus IRES requires association between the cap-binding translation initiation factor (eIF4E) and eIF4G. J Virol 75: 7854-7863.

Allaire M, Chernala MM, Malcolm BA, James MNG. 1994. Picornaviral 3C cysteine proteinases have a fold similar to chymotrypsin-like serine proteinases. Nature 369: 72-76.

Altan-Bonnet N. 2016. Extracellular vesicles are the Trojan horses of viral infection. Curr Opin Microbiol 32: 77-81.

Anderson DA, Ross BC. 1990. Morphogenesis of hepatitis A virus: Isolation and characterization of subviral particles. $J$ Virol 64: 5284-5289.

Anthony SJ, St Leger JA, Liang E, Hicks AL, Sanchez-Leon MD, Jain K, Lefkowitch JH, Navarrete-Macias I, Knowles N, Goldstein T, et al. 2015. Discovery of a novel hepatovirus (phopivirus of seals) related to human hepatitis A virus. MBio 6: $4 \mathrm{e} 01180$.

Asher LV, Binn LN, Mensing TL, Marchwicki RH, Vassell RA, Young GD. 1995. Pathogenesis of hepatitis A in orally inoculated owl monkeys (Aotus trivirgatus). J Med Virol 47: 260-268.
Baroudy BM, Ticehurst JR, Miele TA, Maizel JV Jr, Purcell RH, Feinstone SM. 1985. Sequence analysis of hepatitis A virus cDNA coding for capsid proteins and RNA polymerase. Proc Natl Acad Sci 82: 2143-2147.

Beales LP, Holzenburg A, Rowlands DJ. 2003. Viral internal ribosome entry site structures segregate into two distinct morphologies. J Virol 77: 6574-6579.

Beneduce F, Ciervo A, Kusov Y, Gauss-Muller V, Morace G. 1999. Mapping of protein domains of hepatitis A virus $3 \mathrm{AB}$ essential for interaction with $3 \mathrm{CD}$ and viral RNA. Virology 264: 410-421.

Binn LN, Lemon SM, Marchwicki RH, Redfield RR, Gates NL, Bancroft WH. 1984. Primary isolation and serial passage of hepatitis A virus strains in primate cell cultures. $J$ Clin Microbiol 20: 28-33.

Binn LN, Bancroft WH, Eckels KH, Marchwicki RH, Dubois DR, Asher LVS, LeDuc JW, Trahan CJ, Burke DS, Zuckerman AJ. 1988. Inactivated hepatitis A virus vaccine produced in human diploid MRC-5 cells. In Viral hepatitis and liver disease, pp. 91-93. Alan R. Liss, New York.

Bishop NE, Anderson DA. 1993. RNA-dependent cleavage of VP0 capsid protein in provirions of hepatitis A virus. Virology 197: 616-623.

Bishop NE, Anderson DA. 2000. Uncoating kinetics of hepatitis A virus virions and provirions. J Virol 74: 34233426.

Blank CA, Anderson DA, Beard M, Lemon SM. 2000. Infection of polarized cultures of human intestinal epithelial cells with hepatitis A virus: Vectorial release of progeny virions through apical cellular membranes. J Virol 74: 6476-6484.

Blight KJ, McKeating JA, Rice CM. 2002. Highly permissive cell lines for subgenomic and genomic hepatitis $\mathrm{C}$ virus RNA replication. J Virol 76: 13001-13014.

Bobrie A, Colombo M, Raposo G, Thery C. 2011. Exosome secretion: Molecular mechanisms and roles in immune responses. Traffic 12: 1659-1668.

Borman AM, Kean KM. 1997. Intact eukaryotic initiation factor $4 \mathrm{G}$ is required for hepatitis A virus internal initiation of translation. Virology 237: 129-136.

Brack K, Frings W, Dotzauer A, Vallbracht A. 1998. A cytopathogenic, apoptosis-inducing variant of hepatitis A virus. J Virol 72: 3370-3376.

Brown EA, Day SP, Jansen RW, Lemon SM. 1991a. The $5^{\prime}$ nontranslated region of hepatitis A virus RNA: Secondary structure and elements required for translation in vitro. $J$ Virol 65: 5828-5838.

Brown EA, Day SP, Jansen RW, Lemon SM. 1991b. Genetic variability within the $5^{\prime}$ nontranslated region of hepatitis A virus RNA: Implications for secondary structure and function. J Hepatol 13: S138-143.

Brown EA, Zajac AJ, Lemon SM. 1994. In vitro characterization of an internal ribosomal entry site (IRES) present within the $5^{\prime}$ nontranslated region of hepatitis A virus RNA: Comparison with the IRES of encephalomyocarditis virus. J Virol 68: 1066-1074.

Chang KH, Brown EA, Lemon SM. 1993. Cell type-specific proteins which interact with the $5^{\prime}$ nontranslated region of hepatitis A virus RNA. J Virol 67: 6716-6725.

Chernaia MM, Malcolm BA, Allaire M, James MNG. 1993. Hepatitis A virus 3C proteinase: Some properties, crystal- 
lization and preliminary crystallographic characterization. J Mol Biol 234: 890-893.

Cho MW, Ehrenfeld E. 1991. Rapid completion of the replication cycle of hepatitis A virus subsequent to reversal of guanidine inhibition. Virology 180: 770-780.

Ciervo A, Beneduce F, Morace G. 1998. Polypeptide 3AB of hepatitis A virus is a transmembrane protein. Biochem Biophys Res Commun 249: 266-274.

Clayton A, Turkes A, Dewitt S, Steadman R, Mason MD, Hallett MB. 2004. Adhesion and signaling by B cell-derived exosomes: The role of integrins. FASEB J 18: 977979.

Cohen JI, Ticehurst JR, Feinstone SM, Rosenblum B, Purcell RH. 1987a. Hepatitis A virus cDNA and its RNA transcripts are infectious in cell culture. J Virol 61: 3035-3039.

Cohen JI, Ticehurst JR, Purcell RH, Buckler-White A, Baroudy BM. 1987b. Complete nucleotide sequence of wildtype hepatitis A virus: Comparison with different strains of hepatitis A virus and other picornaviruses. J Virol 61: 50-59.

Cohen L, Benichou D, Martin A. 2002. Analysis of deletion mutants indicates that the $2 \mathrm{~A}$ polypeptide of hepatitis A virus participates in virion morphogenesis. J Virol 76: 7495-7505.

Counihan NA, Daniel LM, Chojnacki J, Anderson DA. 2006. Infrared fluorescent immunofocus assay (IR-FIFA) for the quantitation of non-cytopathic and minimally cytopathic viruses. J Virol Methods 133: 62-69.

Daemer RJ, Feinstone SM, Gust ID, Purcell RH. 1981. Propagation of human hepatitis A virus in African green monkey kidney cell culture: Primary isolation and serial passage. Infect Immun 32: 388-393.

Das A, Hirai-Yuki A, Gonzalez-Lopez O, Rhein B, MollerTank S, Brouillette R, Hensley L, Misumi I, Lovell W, Cullen JM, et al. 2017. TIM1 (HAVCR1) is not essential for cellular entry of either quasi-enveloped or naked hepatitis A virions. mBio 8: e00969.

Day SP, Murphy P, Brown EA, Lemon SM. 1992. Mutations within the $5^{\prime}$ nontranslated region of hepatitis A virus RNA which enhance replication in BS-C-1 cells. J Virol 66: 6533-6540.

Drexler JF, Corman VM, Lukashev AN, van den Brand JM, Gmyl AP, Brunink S, Rasche A, Seggewibeta N, Feng H, Leijten LM, et al. 2015. Evolutionary origins of hepatitis A virus in small mammals. Proc Natl Acad Sci 112: 15190 15195.

Emerson SU, Huang YK, Purcell RH. 1993. 2B and 2C mutations are essential but mutations throughout the genome of HAV contribute to adaptation to cell culture. Virology 194: 475-480.

Emerson SU, Huang YK, Nguyen H, Brockington A, Govindarajan S, St Claire M, Shapiro M, Purcell RH. 2002. Identification of VP1/2A and $2 \mathrm{C}$ as virulence genes of hepatitis $\mathrm{A}$ virus and demonstration of genetic instability of 2C. J Virol 76: 8551-8559.

Esser-Nobis K, Harak C, Schult P, Kusov Y, Lohmann V. 2015. Novel perspectives for hepatitis A virus therapy revealed by comparative analysis of hepatitis $\mathrm{C}$ virus and hepatitis A virus RNA replication. Hepatology 62: 397-408.
Feigelstock D, Thompson P, Mattoo P, Zhang Y, Kaplan GG. 1998. The human homolog of HAVcr-1 codes for a hepatitis A virus cellular receptor. J Virol 72: 6621-6628.

Feinstone SM, Kapikian AZ, Purcell RH. 1973. Hepatitis A: Detection by immune electron microscopy of a viruslike antigen associated with acute illness. Science 182: 10261028.

* Feng Z, Lemon SM. 2018. Innate immunity to enteric hepatitis viruses. Cold Spring Harb Perspect Med doi: 10.1101/ cshperspect.a033464.

Feng D, Zhao WL, Ye YY, Bai XC, Liu RQ, Chang LF, Zhou Q, Sui SF. 2010. Cellular internalization of exosomes occurs through phagocytosis. Traffic 11: 675-687.

Feng Z, Hensley L, McKnight KL, Hu F, Madden V, Ping L, Jeong SH, Walker C, Lanford RE, Lemon SM. 2013. A pathogenic picornavirus acquires an envelope by hijacking cellular membranes. Nature 496: 367-371.

Feng Z, Hirai-Yuki A, McKnight KL, Lemon SM. 2014. Naked viruses that aren't always naked: Quasi-enveloped agents of acute hepatitis. Annu Rev Virol 1: 539-560.

Feng Z, Li Y, McKnight KL, Hensley L, Lanford RE, Walker CM, Lemon SM. 2015. Human pDCs preferentially sense enveloped hepatitis A virions. J Clin Invest 125: 169-176.

Funkhouser AW, Purcell RH, D'Hondt E, Emerson SU. 1994. Attenuated hepatitis A virus: Genetic determinants of adaptation to growth in MRC-5 cells. J Virol 68: 148157.

Gauss-Muller V, Deinhardt F. 1984. Effect of hepatitis A virus infection on cell metabolism in vitro. Proc Soc Exp Biol Med 175: 10-15.

Glass MJ, Jia XY, Summers DF. 1993. Identification of the hepatitis A virus internal ribosome entry site: In vivo and in vitro analysis of bicistronic RNAs containing the HAV $5^{\prime}$ noncoding region. Virology 193: 842-852.

Gosert R, Cassinotti P, Siegl G, Weitz M. 1996. Identification of hepatitis A virus non-structural protein $2 \mathrm{~B}$ and its release by the major virus protease 3C. J Gen Virol 77: 247255.

Gosert R, Chang KH, Rijnbrand R, Yi M, Sangar DV, Lemon SM. 2000a. Transient expression of cellular polypyrimidine-tract binding protein stimulates cap-independent translation directed by both picornaviral and flaviviral internal ribosome entry sites in vivo. Mol Cell Biol 20: 1583-1595.

Gosert R, Egger D, Bienz K. 2000b. A cytopathic and a cell culture adapted hepatitis A virus strain differ in cell killing but not in intracellular membrane rearrangements. Virology 266: 157-169.

Graff J, Cha J, Blyn LB, Ehrenfeld E. 1998. Interaction of poly $(\mathrm{rC})$ binding protein 2 with the $5^{\prime}$ noncoding region of hepatitis A virus RNA and its effects on translation. J Virol 72: 9668-9675.

Graff J, Richards OC, Swiderek KM, Davis MT, Rusnak F, Harmon SA, Jia XY, Summers DF, Ehrenfeld E. 1999. Hepatitis A virus capsid protein VP1 has a heterogeneous C terminus. J Virol 73: 6015-6023.

Gust ID, Coulepis AG, Feinstone SM, Locarnini SA, Moritsugu Y, Najera R, Siegl G. 1983. Taxonomic classification of hepatitis A virus. Intervirology 20: 1-7. 
Gust ID, Lehmann NI, Crowe S, McCrorie M, Locarnini SA Lucas CR. 1985. The origin of the HM175 strain of hepatitis A virus. J Infect Dis 151: 365-367.

Hardin CC, Sneeden JL, Lemon SM, Brown IIB, Guenther RH, Sierzputowska-Gracz H. 1999. Folding of pyrimidine-enriched RNA fragments from the vicinity of the internal ribosomal entry site of hepatitis A virus. Nucleic Acids Res 27: 665-673.

Harmon SA, Emerson SU, Huang YK, Summers DF, Ehrenfeld E. 1995. Hepatitis A viruses with deletions in the 2A gene are infectious in cultured cells and marmosets. Virol 69: 5576-5581.

Hirai-Yuki A, Hensley L, McGivern DR, Gonzalez-Lopez O, Das A, Feng H, Sun L, Wilson JE, Hu F, Feng Z, et al. 2016a. MAVS-dependent host species range and pathogenicity of human hepatitis A virus. Science 353: 15411545.

Hirai-Yuki A, Hensley L, Whitmire JK, Lemon SM. 2016b. Biliary secretion of quasi-enveloped human hepatitis A virus. MBio 7: e01998.

Hoshino A, Costa-Silva B, Shen TL, Rodrigues G, Hashimoto A, Tesic Mark M, Molina H, Kohsaka S, Di Giannatale A, Ceder S, et al. 2015. Tumour exosome integrins determine organotropic metastasis. Nature 527: 329-335.

Hurley JH. 2010. The ESCRT complexes. Crit Rev Biochem Mol Biol 45: 463-487.

Hurley JH. 2015. ESCRTs are everywhere. EMBO J 34: 23982407.

Innis BL, Snitbhan R, Kunasol P, Laorakpongse T, Poopatanakool W, Kozik CA, Suntayakorn S, Suknuntapong T, Safary A, Tang DB, et al. 1994. Protection against hepatitis A by an inactivated vaccine. JAMA 271: 1328-1334.

Jecht M, Probst C, Gauss-Muller V. 1998. Membrane permeability induced by hepatitis A virus proteins $2 \mathrm{~B}$ and $2 \mathrm{BC}$ and proteolytic processing of HAV 2BC. Virology 252: $218-227$.

Jiang P, Liu Y, Ma HC, Paul AV, Wimmer E. 2014a. Picornavirus morphogenesis. Microbiol Mol Biol Rev 78: 418437.

Jiang X, Kanda T, Wu S, Nakamoto S, Saito K, Shirasawa H, Kiyohara T, Ishii K, Wakita T, Okamoto H, et al. 2014b. Suppression of La antigen exerts potential antiviral effects against hepatitis A virus. PLoS ONE 9: e101993.

Kaplan G, Totsuka A, Thompson P, Akatsuka T, Moritsugu Y, Feinstone SM. 1996. Identification of a surface glycoprotein on African green monkey kidney cells as a receptor for hepatitis A virus. EMBO J 15: 4282-4296.

King AMQ, Adams MJ, Carstens EB, Lefkowitz EJ. 2012. Virus taxonomy: Ninth report of the international committee on taxonomy of viruses. Elsevier, New York.

Kusov Y, Weitz M, Dollenmeier G, Gauss-Muller V, Siegl G. 1996. RNA-protein interactions at the $3^{\prime}$ end of the hepatitis A virus RNA. J Virol 70: 1890-1897.

Kusov YY, Morace G, Probst C, Gauss-Muller V. 1997. Interaction of hepatitis A virus (HAV) precursor proteins $3 \mathrm{AB}$ and $3 \mathrm{ABC}$ with the $5^{\prime}$ and $3^{\prime}$ termini of the HAV RNA. Virus Res 51: 151-157.

Kusov YY, Probst C, Jecht M, Jost PD, Gauss-Muller V. 1998 Membrane association and RNA binding of recombinant hepatitis A virus protein 2C. Arch Virol 143: 931-944.
Lemon SM, Binn LN. 1983a. Antigenic relatedness of two strains of hepatitis A virus determined by cross-neutralization. Infect Immun 42: 418-420.

Lemon SM, Binn LN. 1983b. Serum neutralizing antibody response to hepatitis A virus. J Infect Dis 148: 1033-1039.

Lemon SM, Binn LN, Marchwicki RH. 1983. Radioimmunofocus assay for quantitation of hepatitis A virus in cell cultures. J Clin Microbiol 17: 834-839.

Lemon SM, Jansen RW, Newbold JE. 1985. Infectious hepatitis A virus particles produced in cell culture consist of three distinct types with different buoyant densities in CsCl. J Virol 54: 78-85.

Lemon SM, Binn LN, Marchwicki R, Murphy PC, Ping LH, Jansen RW, Asher LV, Stapleton JT, Taylor DG, LeDuc JW. 1990. In vivo replication and reversion to wild type of a neutralization-resistant antigenic variant of hepatitis A virus. J Infect Dis 161: 7-13.

Lemon SM, Murphy PC, Shields PA, Ping LH, Feinstone SM, Cromeans T, Jansen RW. 1991. Antigenic and genetic variation in cytopathic hepatitis A virus variants arising during persistent infection: Evidence for genetic recombination. J Virol 65: 2056-2065.

Lemon SM, Murphy PC, Provost PJ, Chalikonda I, Davide JP, Schofield TL, Nalin DR, Lewis JA. 1997. Immunoprecipitation and virus neutralization assays demonstrate qualitative differences between protective antibody responses to inactivated hepatitis A vaccine and passive immunization with immune globulin. J Infect Dis 176: 9-19.

Martin A, Lemon SM. 2002. The molecular biology of hepatitis A virus. In Hepatitis viruses (ed. Ou J), pp. 23-50. Kluwer, Norwell, MA.

Martin A, Escriou N, Chao SF, Girard M, Lemon SM, Wychowski C. 1995. Identification and site-directed mutagenesis of the primary $(2 \mathrm{~A} / 2 \mathrm{~B})$ cleavage site of the hepatitis A virus polyprotein: Functional impact on the infectivity of HAV RNA transcripts. Virology 213: 213 222.

Martin A, Benichou D, Chao SF, Cohen LM, Lemon SM. 1999. Maturation of the hepatitis A virus capsid protein VP1 is not dependent on processing by the 3 Cpro proteinase. J Virol 73: 6220-6227.

Mathiesen LR, Drucker J, Lorenz D, Wagner J, Gerety RJ, Purcell RH. 1978. Localization of hepatitis A antigen in marmoset organs during acute infection with hepatitis A virus. J Infect Dis 138: 369-377.

Mathivanan S, Ji H, Simpson RJ. 2010. Exosomes: Extracellular organelles important in intercellular communication. J Proteomics 73: 1907-1920.

McKnight KL, Xie L, Gonzalez-Lopez O, Rivera-Serrano EE, Chen X, Lemon SM. 2017. Protein composition of the hepatitis A virus quasi-envelope. Proc Natl Acad Sci 114: $6587-6592$.

Midthun K, Ellerbeck E, Gershman K, Calandra G, Krah D, McCaughtry M, Nalin D, Provost P. 1991. Safety and immunogenicity of a live attenuated hepatitis A virus vaccine in seronegative volunteers. J Infect Dis 163: 735-739.

Moller-Tank S, Kondratowicz AS, Davey RA, Rennert PD, Maury W. 2013. Role of the phosphatidylserine receptor TIM-1 in enveloped-virus entry. J Virol 87: 8327-8341. 
Najarian R, Caput D, Gee W, Potter SJ, Renard A, Merryweather J, Van Nest G, Dina D. 1985. Primary structure and gene organization of human hepatitis A virus. Proc Natl Acad Sci 82: 2627-2631.

Nuesch JP, Weitz M, Siegl G. 1993. Proteins specifically binding to the $3^{\prime}$ untranslated region of hepatitis A virus RNA in persistently infected cells. Arch Virol 128: 65-79.

Ogram SA, Flanegan JB. 2011. Non-template functions of viral RNA in picornavirus replication. Curr Opin Virol 1: 339-346.

Panjwani A, Strauss M, Gold S, Wenham H, Jackson T, Chou JJ, Rowlands DJ, Stonehouse NJ, Hogle JM, Tuthill TJ 2014. Capsid protein VP4 of human rhinovirus induces membrane permeability by the formation of a size-selective multimeric pore. PLoS Pathog 10: e1004294.

Paul AV, Yin J, Mugavero J, Rieder E, Liu Y, Wimmer E. 2003. A "slide-back" mechanism for the initiation of protein-primed RNA synthesis by the RNA polymerase of poliovirus. J Biol Chem 278: 43951-43960.

Ping LH, Lemon SM. 1992. Antigenic structure of human hepatitis A virus defined by analysis of escape mutants selected against murine monoclonal antibodies. J Virol 66: 2208-2216.

Pintó RM, Aragones L, Costafreda MI, Ribes E, Bosch A 2007. Codon usage and replicative strategies of hepatitis A virus. Virus Res 127: 158-163.

* Pintó RM, Pérez-Rodríguez F-J, D’Andrea L, de Castellarnau M, Guix S, Bosch A. 2018. HAV codon usage: Implications for translation kinetics and capsid folding. Cold Spring Harb Perspect Med doi: 10.1101/cshperspect. a031781.

Pisani G, Beneduce F, Gauss-Muller V, Morace G. 1995. Recombinant expression of hepatitis A virus protein 3A: Interaction with membranes. Biochem Biophys Res Commun 211: 627-638.

Probst C, Jecht M, Gauss-Muller V. 1998. Processing of proteinase precursors and their effect on hepatitis A virus particle formation. J Virol 72: 8013-8020.

Probst C, Jecht M, Gauss-Muller V. 1999. Intrinsic signals for the assembly of hepatitis A virus particles: Role of structural proteins VP4 and 2A. J Biol Chem 274: 45274531.

Provost PJ, Hilleman MR. 1979. Propagation of human hepatitis A virus in cell culture in vitro. Proc Soc Exp Biol Med 160: 213-221.

Provost PJ, Giesa PA, McAleer WJ, Hilleman MR. 1981. Isolation of hepatitis A virus in vitro in cell culture directly from human specimens. Proc Soc Exp Biol Med 167: 201206.

Provost PJ, Conti PA, Giesa PA, Banker FS, Buynak EB, McAleer WJ, Hilleman MR. 1983. Studies in chimpanzees of live, attenuated hepatitis A vaccine candidates. Proc Soc Exp Biol Med 172: 357-363.

Qu L, Feng Z, Yamane D, Liang Y, Lanford RE, Li K, Lemon SM. 2011. Disruption of TLR3 signaling due to cleavage of TRIF by the hepatitis A virus protease-polymerase processing intermediate, 3CD. PLoS Pathog 7: e1002169.

Ren X, Hurley JH. 2011. Proline-rich regions and motifs in trafficking: From ESCRT interaction to viral exploitation. Traffic 12: 1282-1290.
Rueckert RR, Wimmer E. 1984. Systematic nomenclature of picornavirus proteins. J Virol 50: 957-959.

* Sander A-L, Corman VM, Lukashev AN, Drexler JF. 2018. Evolutionary origins of enteric hepatitis viruses. Cold Spring Harb Perspect Med doi: 10.1101/cshperspect. a031690.

Schmitz G, Dotzauer A. 1998. Proof of hepatitis A virus negative-sense RNA by RNA/DNA-hybrid detection: A method for specific detection of both viral negative- and positive-strand RNA species. Nucleic Acids Res 26: 52305232.

Scholz E, Heinricy U, Flehmig B. 1989. Acid stability of hepatitis A virus. J Gen Virol 70: 2481-2485.

Schultheiss T, Kusov YY, Gauss-Muller V. 1994. Proteinase $3 \mathrm{C}$ of hepatitis A virus (HAV) cleaves the HAV polyprotein $\mathrm{P} 2-\mathrm{P} 3$ at all sites including VP1/2A and 2A/2B. $V i$ rology 198: 275-281.

Schultz DE, Hardin CC, Lemon SM. 1996a. Specific interaction of glyceraldehyde 3-phosphate dehydrogenase with the $5^{\prime}$-nontranslated RNA of hepatitis A virus. J Biol Chem 271: 14134-14142.

Schultz DE, Honda M, Whetter LE, McKnight KL, Lemon SM. 1996b. Mutations within the $5^{\prime}$ nontranslated RNA of cell culture-adapted hepatitis A virus which enhance cap-independent translation in cultured African green monkey kidney cells. J Virol 70: 1041-1049.

Shaffer DR, Lemon SM. 1995. Temperature-sensitive hepatitis A virus mutants with deletions downstream of the first pyrimidine-rich tract of the $5^{\prime}$ nontranslated RNA are impaired in RNA synthesis. J Virol 69: 6498-6506.

Shaffer DR, Brown EA, Lemon SM. 1994. Large deletion mutations involving the first pyrimidine-rich tract of the $5^{\prime}$ nontranslated RNA of human hepatitis A virus define two adjacent domains associated with distinct replication phenotypes. J Virol 68: 5568-5578.

* Shouval D. 2018. Immunization against hepatitis A. Cold Spring Harb Perspect Med doi: 10.1101/cshperspect. a031682.

Shukla A, Padhi AK, Gomes J, Banerjee M. 2014. The VP4 peptide of hepatitis A virus ruptures membranes through formation of discrete pores. J Virol 88: 12409-12421.

Siegl G, Weitz M, Kronauer G. 1984. Stability of hepatitis A virus. Intervirology 22: 218-226.

Snooks MJ, Bhat P, Mackenzie J, Counihan NA, Vaughan N, Anderson DA. 2008. Vectorial entry and release of hepatitis A virus in polarized human hepatocytes. J Virol 82: 8733-8742.

Stapleton JT, Lemon SM. 1987. Neutralization escape mutants define a dominant immunogenic neutralization site on hepatitis A virus. J Virol 61: 491-498.

Stapleton JT, Raina V, Winokur PL, Walters K, Klinzman D, Rosen E, McLinden JH. 1993. Antigenic and immunogenic properties of recombinant hepatitis A virus $14 \mathrm{~S}$ and 70 s subviral particles. J Virol 67: 1080-1085.

Strauss M, Levy HC, Bostina M, Filman DJ, Hogle JM. 2013. RNA transfer from poliovirus $135 \mathrm{~S}$ particles across membranes is mediated by long umbilical connectors. J Virol 87: 3903-3914.

Strauss M, Filman DJ, Belnap DM, Cheng N, Noel RT, Hogle JM. 2015. Nectin-like interactions between poliovirus and 
K.L. McKnight and S.M. Lemon

its receptor trigger conformational changes associated with cell entry. J Virol 89: 4143-4157.

* Stuart DI, Ren J, Wang X, Rao Z, Fry EE. 2018. Hepatitis A virus capsid structure. Cold Spring Harb Perspect Med doi: 10.1101/cshperspect.a031807.

Tesar M, Harmon SA, Summers DF, Ehrenfeld E. 1992. Hepatitis A virus polyprotein synthesis initiates from two alternative AUG codons. Virology 186: 609-618.

Tesar M, Jia XY, Summers DF, Ehrenfeld E. 1993. Analysis of a potential myristoylation site in hepatitis A virus capsid protein VP4. Virology 194: 616-626.

Tesar M, Pak I, Jia XY, Richards OC, Summers DF, Ehrenfeld E. 1994. Expression of hepatitis A virus precursor protein $\mathrm{P} 3$ in vivo and in vitro: Polyprotein processing of the $3 \mathrm{CD}$ cleavage site. Virology 198: 524-533.

Teterina NL, Bienz K, Egger D, Gorbalenya AE, Ehrenfeld E. 1997. Induction of intracellular membrane rearrangements by HAV proteins 2C and 2BC. Virology 237: 66-77.

Tian T, Zhu YL, Zhou YY, Liang GF, Wang YY, Hu FH, Xiao ZD. 2014. Exosome uptake through clathrin-mediated endocytosis and macropinocytosis and mediating miR21 delivery. J Biol Chem 289: 22258-22267.

Ticehurst JR, Racaniello VR, Baroudy BM, Baltimore D, Purcell RH, Feinstone SM. 1983. Molecular cloning and characterization of hepatitis A virus cDNA. Proc Natl Acad Sci 80: 5885-5889.

van Dongen HM, Masoumi N, Witwer KW, Pegtel DM. 2016. Extracellular vesicles exploit viral entry routes for cargo delivery. Microbiol Mol Biol Rev 80: 369-386.

Wang X, Ren J, Gao Q, Hu Z, Sun Y, Li X, Rowlands DJ, Yin W, Wang J, Stuart DI, et al. 2015. Hepatitis A virus and the origins of picornaviruses. Nature 517: 85-88.

Weitz M, Baroudy BM, Maloy WL, Ticehurst JR, Purcell RH. 1986. Detection of a genome-linked protein (VPg) of hepatitis A virus and its comparison with other picornaviral VPgs. J Virol 60: 124-130.

Werzberger A, Mensch B, Kuter B, Brown L, Lewis J, Sitrin R, Miller W, Shouval D, Wiens B, Calandra G, et al. 1992. A controlled trial of a formalin-inactivated hepatitis A vaccine in healthy children. $N$ Engl J Med 327: 453-457.

Whetter LE, Day SP, Elroy-Stein O, Brown EA, Lemon SM. 1994. Low efficiency of the $5^{\prime}$ nontranslated region of hepatitis A virus RNA in directing cap-independent translation in permissive monkey kidney cells. J Virol 68: 5253-5263.

Yang Y, Liang Y, Qu L, Chen Z, Yi M, Li K, Lemon SM. 2007. Disruption of innate immunity due to mitochondrial targeting of a picornaviral protease precursor. Proc Natl Acad Sci 104: 7253-7258.

Yang Y, Yi M, Evans DJ, Simmonds P, Lemon SM. 2008. Identification of a conserved RNA replication element (cre) within the $3 \mathrm{D}^{\mathrm{pol}}$-coding sequence of hepatoviruses. J Virol 82: 10118-10128.

Yi M, Lemon SM. 2002. Replication of subgenomic hepatitis A virus RNAs expressing firefly luciferase is enhanced by mutations associated with adaptation of virus to growth in cultured cells. J Virol 76: 1171-1180.

Yi M, Schultz DE, Lemon SM. 2000. Functional significance of the interaction of hepatitis A virus RNA with glyceraldehyde 3-phosphate dehydrogenase (GAPDH): opposing effects of GAPDH and polypyrimidine tract binding protein on internal ribosome entry site function. J Virol 74: 6459-6468.

Yin X, Ambardekar C, Lu Y, Feng Z. 2016. Distinct entry mechanisms for nonenveloped and quasi-enveloped hepatitis E viruses. J Virol 90: 4232-4242.

Yu JM, Li LL, Zhang CY, Lu S, Ao YY, Gao HC, Xie ZP, Xie GC, Sun XM, Pang LL, et al. 2016. A novel hepatovirus identified in wild woodchuck Marmota himalayana. Sci Rep 6: 22361.

Zhang HC, Chao SF, Ping LH, Grace K, Clarke B, Lemon SM. 1995. An infectious cDNA clone of a cytopathic hepatitis A virus: Genomic regions associated with rapid replication and cytopathic effect. Virology 212: 686697. 


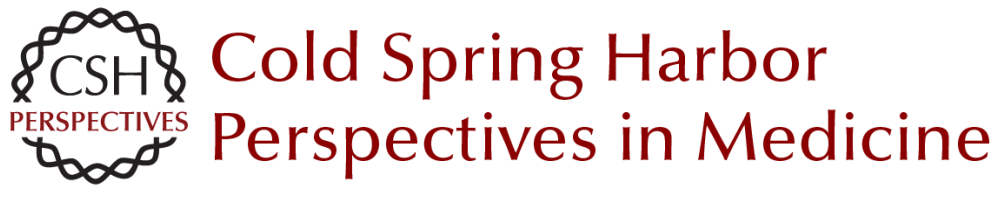

\section{Hepatitis A Virus Genome Organization and Replication Strategy}

Kevin L. McKnight and Stanley M. Lemon

Cold Spring Harb Perspect Med 2018; doi: 10.1101/cshperspect.a033480 originally published online April 2, 2018

\section{Subject Collection Enteric Hepatitis Viruses}

Hepatitis A Virus Genome Organization and Replication Strategy

Kevin L. McKnight and Stanley M. Lemon

Adaptive Immune Responses in Hepatitis A Virus and Hepatitis E Virus Infections

Christopher M. Walker

Small Animal Models of Hepatitis E Virus Infection Tian-Cheng Li and Takaji Wakita

Acute and Persistent Hepatitis E Virus Genotype 3 and 4 Infection: Clinical Features, Pathogenesis, and Treatment Nassim Kamar and Sven Pischke

Epidemiology of Genotype 1 and 2 Hepatitis E Virus Infections

Kenrad E. Nelson, Alain B. Labrique and Brittany L. Kmush

History of the Discovery of Hepatitis A Virus Stephen M. Feinstone

Epidemiology and Transmission of Hepatitis A Virus and Hepatitis E Virus Infections in the United States

Megan G. Hofmeister, Monique A. Foster and Eyasu H. Teshale

Stem Cell-Derived Culture Models of Hepatitis E Virus Infection

Viet Loan Dao Thi, Xianfang Wu and Charles $M$. Rice
Evolutionary Origins of Enteric Hepatitis Viruses Anna-Lena Sander, Victor Max Corman, Alexander N. Lukashev, et al.

Enterically Transmitted Non-A, Non-B Hepatitis and the Discovery of Hepatitis E Virus

Stanley M. Lemon and Christopher M. Walker

Natural History, Clinical Manifestations, and

Pathogenesis of Hepatitis E Virus Genotype 1 and

2 Infections

Rakesh Aggarwal and Amit Goel

Hepatitis A Virus and Hepatitis E Virus: Emerging and Re-Emerging Enterically Transmitted

Hepatitis Viruses

Stanley M. Lemon and Christopher M. Walker

Hepatitis A Virus Capsid Structure

David I. Stuart, Jingshan Ren, Xiangxi Wang, et al.

Comparative Pathology of Hepatitis A Virus and Hepatitis E Virus Infection John M. Cullen and Stanley M. Lemon

Innate Immunity to Enteric Hepatitis Viruses Zongdi Feng and Stanley M. Lemon

Nonhuman Primate Models of Hepatitis A Virus and Hepatitis E Virus Infections

Robert E. Lanford, Christopher M. Walker and

Stanley M. Lemon

For additional articles in this collection, see http://perspectivesinmedicine.cshlp.org/cgi/collection/ 